\title{
Poverty, hunger, and abandonment: representations of the nursing team about homeless persons
}

\author{
Pobreza, fome e abandono: representações da equipe de enfermagem sobre pessoas em situação de rua \\ Pobreza, hambre y abandono: representaciones del grupo de enfermería sobre personas sin hogar
}

Mayara Novais Pereira Zandomingo'

ORCID: 0000-0003-3791-6736

Jeane Freitas de Oliveira'

ORCID: 0000-0001-8401-8432

Dejeane de Oliveira Silva" ORCID: 0000-0002-1798-3758

Carle Porcino'

ORCID: 0000-0001-6392-0291

Cleuma Sueli Santos Suto' ORCID: 0000-0002-6427-5535

Daiane Santos Oliveira' ORCID: 0000-0002-0252-441X

'Universidade Federal da Bahia. Salvador, Bahia, Brazil. "Universidade Estadual de Santa Cruz. Ilhéus, Bahia, Brazil.

How to cite this article: Zandomingo MNP, Oliveira JF, Silva DO, Porcino, Suto CS, Oliveira DS. Poverty, Hunger, and Abandonment: Representations of the Nursing Staff about Homeless Persons. Rev Bras Enferm. 2020;73(Suppl 1):e20190338. doi: http://dx.doi.org/10.1590/0034-7167-2019-0338

How to cite this article:

Mayara Novais Pereira Zandomingo

E-mail: novais_mayara@yahoo.com.br

EDITOR IN CHIEF: Antonio José de Almeida Filho ASSOCIATE EDITOR: Hugo Fernandes

Submission: 04-23-2019 Approval: 09-26-2019

\begin{abstract}
Objective: to know the structure of social representations of nursing team with regard to homeless persons. Method: a qualitative research based on the structural approach of social representations. A total of 96 professionals from the nursing team working in the Psychosocial Care Network units of a Health District of Salvador, Bahia, Brazil, who answered the test of free association of words and a questionnaire with socio-demographic data. The data obtained were processed in softwares that allowed the organization of the frame of four houses and maximum similarity tree. Results: poverty, hunger, abandonment and unemployment are central elements of the image of homeless persons, living in a context permeated by drugs, dirt, neglect and vulnerability. Final considerations: The social representation structure of homeless persons is anchored in stereotypes that can interfere both in the provision of care and in the access of the people to health services.

Descriptors: Poverty; Hunger; Homeless Persons; Nursing, Team; Qualitative Research.
\end{abstract}

\section{RESUMO}

Objetivo: conhecer a estrutura das representações sociais da equipe de enfermagem acerca de pessoas em situação de rua. Método: pesquisa qualitativa, fundamentada na abordagem estrutural das representações sociais. Foram abordadas 96 profissionais da equipe de enfermagem atuantes na Rede de Atenção Psicossocial de um Distrito Sanitário de Salvador, Bahia, que responderam ao Teste de Associação Livre de Palavras e questionário com dados sociodemográficos. Os dados foram processados em softwares que permitiram organização do quadro de quatro casas e árvore máxima de similitude. Resultados: pobreza, fome, abandono e desemprego constitui possíveis elementos centrais da imagem da pessoa em situação de rua que vive em um contexto permeado por drogas, sujeira, descaso e vulnerabilidades. Considerações finais: a estrutura da representação social da pessoa em situação de rua está ancorada em estereótipos que podem interferir tanto na prestação do cuidado, quanto no acesso das pessoas em situação de rua aos serviços de saúde.

Descritores: Pobreza; Fome; Pessoas em Situação de Rua; Equipe de Enfermagem; Pesquisa Qualitativa.

\section{RESUMEN}

Objetivo: conoce la estructura de las representaciones sociales del equipo de enfermería acerca de personas sin hogar. Método: investigación cualitativa con enfoque estructural de las representaciones sociales. Se abordaron 96 profesionales del equipo de enfermería, actuantes en unidades de Red de Atención Psicosocial de un Distrito Sanitario de el cuidad de Salvador, estado de Bahia, Brasil, que respondieron a la Prueba de Asociación Libre de Palabras y cuestionario con datos sociodemográficos. Los datos fueron procesados en softwares que permitieron organizar el cuadro de cuatro casas y árbol máximo de similitud. Resultados: pobreza, hambre, abandono y desempleo constituyen elementos centrales de la imagen de la persona sin hogar, que vive en un contexto impregnado por las drogas, suciedad, descuido y vulnerabilidades. Consideraciones finales: la estructura de la representación social de la persona sin hogar está anclada en estereotipos que pueden interferir en la prestación del cuidado, como en el acceso de estas personas a los servicios de salud.

Descriptores: Pobreza; Hambre; Personas sin Hogar; Grupo de Enfermería; Investigación Cualitativa. 


\section{INTRODUCTION}

The Psychosocial Care Network (RAPS - Rede de Atenção Psicossocial) encompasses a range of primary care, urgency/emergency and specialized care equipment. It aims to serve people with needs arising from psychological distress and the use of alcohol and other drugs. One of its guidelines is to care for people in vulnerable situations. These guidelines include homeless persons (HP) through the establishment of a Unique Therapeutic Project (PTS - Projeto Terapêutico Singular) and support from a multidisciplinary staff acting on the logic of interdisciplinarity ${ }^{(1)}$. In these RAPS equipment, the professionals must share user care, forming a cohesive network with diversity of strategies that meet the specificities of the person.

The nursing staff, composed of nurses, nursing technicians and assistants, holds a large number of health professionals in the Brazilian Health System (SUS - Sistema Único de Saúde). It is present in the composition of most services, in the three levels of care ${ }^{(2)}$. Their work is related to the care process, highlighting it in health services, in direct and frequent contact with HP. The performance of the nursing staff with HP in RAPS varies according to the characteristics of the service and its attributions in the context of the multidisciplinary staff( ${ }^{(3)}$.

HP are a heterogeneous group regarding gender, race, generation and other social markers, but with some aspects in common. In Brazil, HP are defined as a group that has in common extreme poverty, weakening or breaking family ties and lack of regular housing. It makes use of public places or degraded places as living space and/or livelihood ${ }^{(4)}$. By inhabiting large urban centers, exposing their private lives in public space, HP challenge the model of society that overemphasizes privacy and property ${ }^{(5)}$.

Poor street living conditions make HP more likely to suffer lifestyle-related injuries and health problems. These conditions include poor nutrition due to uncertain diet, exposure to weather elements and situations of violence such as assaults and beatings ${ }^{(6)}$. Access to and quality of water, sleep deprivation and affection are also factors that affect their health ${ }^{(7)}$. In addition, they present significant demands related to mental disorders and the use of alcohol or other drugs, which enhance their vulnerabilities and require health care ${ }^{(8-9)}$.

Poor hygiene, bad smell and the effect of licit and illicit drugs can be a barrier to the reception of HP in health services. It is also common the rigidity in scheduling appointments, restriction on available hours, in addition to the requirement of identity documents, proof of address and Brazilian National Health Card (SUS Card - Cartão Nacional de Saúde) as a condition for care and procedures ${ }^{(10)}$.

In this context, it is necessary to use specific equipment and strategies to meet their demands and needs. Care provision within the SUS requires the plasticity of health services using low demand technologies, such as flexible hours, reception of users even under the influence of psychoactive substances, dispensing of inputs to minimize risks, harm reduction and protection of health and life (e.g., condoms, food, among others) ${ }^{(11)}$.

The poor living conditions of HP expose them to various risk situations as vulnerabilities overlap and make their access to health services difficult. The street situation is permeated by stigmas resulting from socially shared stereotypes and hegemonic representations that reflect on the access of people living in such situation to health services and, consequently, on care practices ${ }^{(12)}$.
The nursing staff is a social group that, when formulating, sharing and dissipating social representations, may influence and/ or be influenced by care practices provided to HP. Thus, knowing the social representations of the nursing staff about homeless persons is relevant for the promotion of possible transformations in their health care practices.

\section{OBJECTIVE}

To know the structure of social representations of the nursing staff about homeless persons.

\section{METHODS}

\section{Ethical aspects}

The research project was approved by the School of Nursing's Research Ethics Committee of the Universidade Federal da Bahia (EEUFBA), observing the ethical principles as provided in Resolution 466/2012, having the CAAE (Certificado de Apresentação para Apreciação Ética - Certificate of Presentation for Ethical Consideration).

\section{Theoretical-methodological framework and Type of study}

It is characterized as a qualitative approach research. Refers to one of the results of Master's research, based on the Theory of Social Representations (TSR), favoring the Theory of the Central Nucleus (TCN), also known as Structural Approach. According to the principles of this approach a social representation is constituted by "an organized and structured set of information, beliefs, opinions and attitudes that constitutes a particular socio-cognitive system, composed of two subsystems: a central system (or central nucleus) and a peripheral system ${ }^{(13)^{\prime \prime}}$.

\section{Methodological procedures}

The investigated group answered the Word Association Test (WAT) and informed sociodemographic data through a form prepared by the researchers themselves, with questions that allowed knowing the social representations (SR) and drawing the profile of the participants.

\section{Study setting}

The research was carried out in nine RAPS facilities of a Health District of Salvador (BA), being: three Basic Health Units (BHU), three Family Health Units (FHU), a Street Outreach Office (SOO), a Type II Psychosocial Care Center (CAPS - Centro de Atenção Psicossocial) and an Emergency Care Unit (ECU).

\section{Data source}

Ninety-six nursing staff professionals participated in the study. Inclusion criteria were being part of the health staff of one of the units / equipment of the district RAPS and being active in the development of care and / or management activities inherent to the nursing staff. Removal from work activities was considered 
as an exclusion criterion. To ensure the anonymity of the research participants, we chose to use the letters NP (Nursing Professional), followed by the number of the order of application of WAP.

\section{Collection and organization of data}

Data collection took place between August and October 2018, in a day and time provided by the participants, in the unit or in the context of professional practice, and in a reserved place, ensuring confidentiality. Two techniques were used: the questionnaire with characterization data; and the technique of free evocations with the inductive term "homeless persons". In the individual application of WAP, participants were asked to record on paper up to five words that came to mind when hearing the term inductor. Then, they were asked to attribute to each evocation a positive (+) or negative (-) connotation, and to choose, from the evoked words, the one classified as the most important, justifying their choice. Then the questionnaire was applied, consisting of open and closed questions, which made it possible to know the profile of the group investigated. This instrument was presented after free evocation to avoid possible influences on data production.

\section{Data analysis}

Sociodemographic data, as well as WAP responses, were transcribed into Microsoft Word software and organized according to the analysis software criteria. The evocations were grouped by semantic content and lemmatized, seeking homogeneity and analytical consistency of the corpus. For the analysis of evocations based on the criteria of frequency and average order of evocation (AOE), we used the EVOC software, $2005^{\circ}$ version, generating the four-box table. To construct the tree similarity algorithm, the Iramuteq Version 0.7 alpha 2 software was used. Afterwards, the data were analyzed and interpreted based on the literature on the subject and anchored in the TSR.

\section{RESULTS}

Of the 96 survey participants, 47 (49\%) were nursing technicians, 45 (46.9\%) were nurses, and four (4.1\%) were nursing assistants. The majority (89.6\%) were female. Regarding race/color, 42 (43.8\%) declared themselves black and 41 (42.7\%) brown, constituting a universe of $86.5 \%$ of black professionals. The participants' ages ranged from 26 to 66 years, with a predominance of the age group from 35 to 44 years (36.5\%). Training time ranged from six months to 35 years, and 39 participants (40.6\%) had between 11 and 20 years of training. In this paper we chose to treat female professionals as women represent the majority of the sample.
In response to the inductive encouragement "homeless persons", 467 words were evoked, of which 34 were distinct. In the data processing in the EVOC software for the construction of the four-house table (Table 1), the minimum frequency of 13, average frequency of 19 and the AOE of 2.8 were considered. The data processing by Iramuteq allowed the elaboration of the tree similarity algorithm, allowing the visualization of the representational field conformation from the connections between the evocations and the inference on the structure of the construction of texts and themes of relative importance (Figure 1). The interpretation of the two images allowed the identification of the structure of social representations, with distinct but complementary elements of the central and peripheral systems.

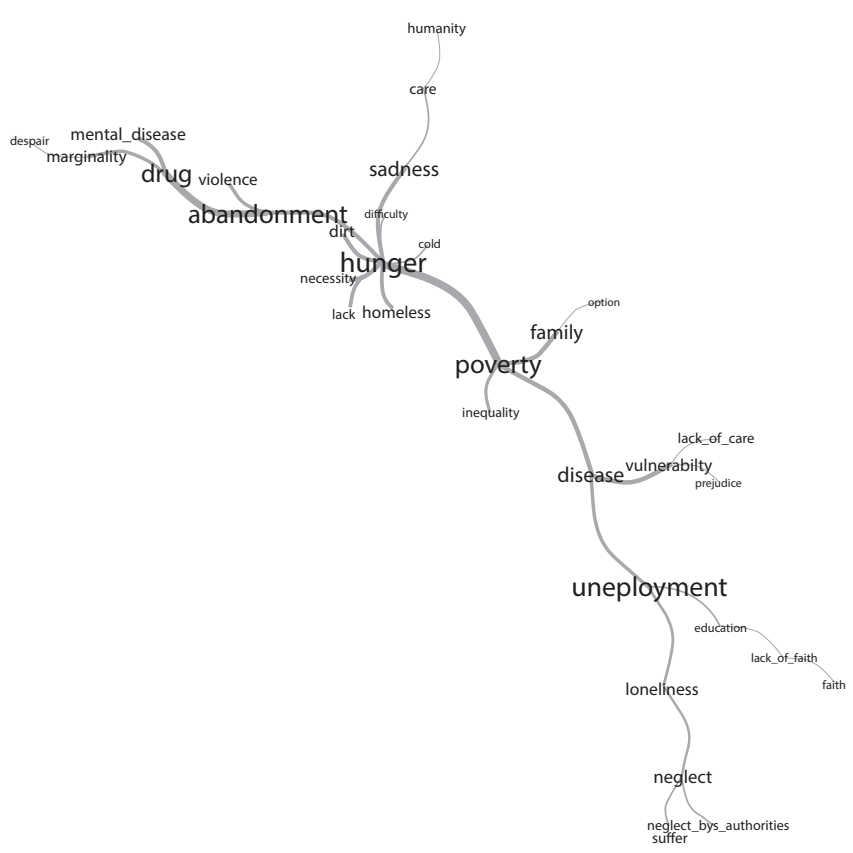

Figure 1-Tree similarity algorithm of the nursing staff's evocations for the inducing encouragement "homeless persons", Salvador, Bahia, Brazil, 2018 


\section{DISCUSSION}

In the four-house table (Table 1), the terms "poverty","hunger", "abandonment", and "unemployment", present in the upper left quadrant, were more readily evoked, that is, they obtained lower AOE and presented higher frequency, being considered possible elements of the central nucleus. In this analysis process, although the term "poverty" ( $f=34 ; A O E=2.27$ ) was the most evoked and obtained the lowest AOE from the probable central nucleus, it was pointed out as the most important by only one participant. It is noteworthy that the term "abandonment" $(\mathrm{f}=33 ; \mathrm{AOE}=2.33)$ was mentioned as the most important by 13 participants. The content of the justifications suggests that for the group investigated HP experience situations of helplessness and abandonment as the following excerpts:

Without the full protection of society, without resources, thrown to "God will give", without food, resources, leisure, in short, without right to anything. (NP 37)

Living abandoned, helpless, away from home/family leads to several negative consequences affecting self-esteem, overall health and suffering. (NP 48)

The terms "hunger" and "unemployment" presented different frequency, but with the same AOE (2.77) and were pointed as the most important by four participants. The content of the justifications signals elements that make up the imaginary dimension of HP:

There is usually no way to feed. Most are drug users and when they have children they end up starving, because they are unattended by their parents and society. (NP 75)

Often, for lack of education-related opportunity or even lack of employment, many will be on the streets. (NP 41)

In the lower left quadrant (Table 1), called the Contrast Zone, the elements with low frequency that were most readily evoked by the participants are located. The elements "neglect" $(f=16$; $A O E=2.38)$, "dirt" ( $f=15 ; A O E=2.80)$ and "vulnerability" ( $f=14$; $\mathrm{AOE}=2.21$ ) reinforce the configuration of the probable central nucleus of social representations, evidenced by abandonment and susceptibility to health problems due to poor conditions to maintain hygiene and access to food, mental disorders and violence. The following justifications fit these elements.

Disregard for rulers and the human being. (NP 65)

I believe that homeless persons are more vulnerable to violence, illness, basic human needs, and less heard in public/private services and other people. (NP 89)

In the upper right quadrant (Table 1) are located the elements that constitute the first periphery, considered the most important of the Peripheral System for conferring protection to the central nucleus and sensitivity to the immediate context ${ }^{(13)}$. The elements "drugs", "diseases", "family" and "sadness" have frequencies of 19 or higher and higher $\mathrm{AOE}$, due to their later evocation.
The element "drugs" $(f=31 ; A O E=3.03)$ had the highest quadrant frequency, being considered the most important term by nine participants. For the nursing staff, drugs appear as a cause for the homeless situation, seen as a devastating element in people's lives or as a refuge and/or protective factor to support the homeless condition:

The use of illicit drugs contributes to the abandonment of family, home, job, and the person, by his addiction, indulges in a situation where he takes to live on the street. (NP 36)

In the streets, the individual is in a vulnerable situation, stigmatized by society and family. From there they seek refuge in drugs in an attempt to forget suffering. (NP 93)

The element "diseases" ( $f=20 ; A O E=3.50$ ) was related to susceptibility of HP, lack of care and difficulty in access to health, which increase the risk factors for physical and mental disorder.

Susceptible to physical, mental and emotional illness. (NP 32)

Lack of access to information. This ultimately results in lack of care and access to health due to poor guidance. (NP 38)

The element "family" ( $f=19 ;$ AOE: 3,53) was considered the most important eleven times, reinforcing its relevance to the social representations of HP. The justifications for the term reveal that the group considers the family as the basis of the individual and point out that going to the streets may be related to the way the family is organized to deal with different situations. As well as family relationships may constitute risk factors or protective factors for the homeless situation, as indicated by the participants:

The family as the basis of the whole organization, becoming disorganized, disorganized thus causes the individual/family conflicts that make them look for drugs, alcohol, etc. (NP 04)

These people are homeless due to the condition of the family [social economic situation], the confrontation of life. (NP 87)

The term "sadness" $(f=19 ; A O E=2.95)$ presented the lowest $A O E$ among the words that make up the right upper quadrant and represents the feelings of compassion that emerge among the nursing staff professionals, when they notice the precariousness of the living conditions of HP.

The elements present in the lower right quadrant (Table 1) represent the terms of the second periphery of the social representations and have the lowest frequencies, and were later evoked by the participants. In this quadrant, elements of heterogeneity of representations are evident as they evoke negative connotation terms such as "mental disorder" ( $f=14 ; A O E=2.93)$, "marginality" $(f=14 ; A O E=3.57)$, "homeless" $(f=15 ; A O E=3.13)$, "loneliness" $(f=14$; $A O E=3.21)$ and "violence" $(f=14 ; A O E=3.71)$. In addition, there are elements of positive connotation such as "care" ( $f=13 ; A O E=3.39)$ and "humanity" ( $f=14 ; A O E=3.36)$. In the following excerpts, the professionals justify the importance of these terms:

For lack of love for each other, especially between family can lead the person to have depression, involvement with drugs and take it to the street for good. (NP 59) 
Homeless persons generally do not have family life, being isolated from the world and having difficulty in relationships due to the constant danger of the street. (NP 44)

That the person who is on the street is vulnerable to various types of violence, whether sexual, banal. (NP 68)

Because they are in marginality is already because they got involved with the drug, already sick. The person ends up stealing to maintain the addiction. (NP 22)

The maximum tree of similarity (Figure 1) reveals the strong relationship between the terms "hunger", "poverty" and "abandonment", pointing to signs of centrality, evidenced by the co-occurrences between the terms. That is, the thicker the line connecting one word to another the stronger the connection between them. At the ends of the tree are the elements that make up the peripheral system of representations, highlighting the terms "family", "drug" and "disease".

The set of terms evoked from the encouragement "homeless persons" and their distribution in four-house table fand the maximum tree of similarity reveal HP image as synonymous with beggar, pauper and tramp. This image is anchored in a vision historically constructed since antiquity when there were already reports of people roaming the streets. With the phenomenon of urbanization and later industrialization in the nineteenth century, this image is accentuated, linked to the lack of productivity of disadvantaged parts of society ${ }^{(14)}$.

The elements present in the probable central nucleus (Table 1) express, for the studied group, the main causes that lead people to homelessness. In the maximum tree of similarity, the elements "poverty" and "hunger" stand out because they form the densest nuclei, expressed by the largest font size and originate branches composed of negative connotation elements. In this sense, HP images for the nursing staff are related to aspects of suffering, misery and deprivation. The terms evoked with positive connotation such as "care" and "humanity" are present in the periphery and show that they are elements coming from a subgroup, among the participants, matching the peripheral elements in Table 1.

In common sense, housing is a protected space, achieved through a source of income, work, which also makes it possible to meet basic needs such as food, health, education, leisure and housing. In the street, the space that was private becomes public, the privacy and shame are lost, because the body is delivered to the street ${ }^{(15)}$. The construction of life that should occur in the private space begins to occur in the public. These aspects seem to cause strangeness to those who are not in the same situation, such as the group investigated.

In contemporary times, the rise in the number of HP is one of the facets of the extreme levels of inequality that keep portions of the population, especially black people, on the fringes of the economy, living below the poverty line ${ }^{(16)}$. The poor living conditions they face every day expose HP to various situations of vulnerability. Overlapping vulnerabilities ultimately makes them vulnerable, experiencing daily violation of citizenship rights ${ }^{(17)}$.

The condition of abandoned refers to the image of the individual who has lost his rights and is excluded, living outside the conventional structures of society. The abandonment by the family and the state makes HP invisible to claim/demand their rights, thus culminating in appealing to the condition of victimization. The idea of abandonment linked to HP ends by labeling them as incapable and poor, disregarding their resilience and the strategies they use to (over) live on and/or on the streets ${ }^{(18)}$.

Given the terms that make up the four-house table and which are reaffirmed in the maximum tree of similarity, it can be inferred that the idea of abandonment attributed to HP adds to the conditions of dirt and drug use that can be barriers to caution. Given that nursing as a profession has as one of its main practices promoting patient hygiene care, such practices enable the risk of denying care to HP and/or using hygienic practices aimed at this public ${ }^{(19)}$. There is no guarantee that being with a clean body is a necessity of all HPs, as they form a heterogeneous group with diverse health demands. It is noteworthy that in the context of the street, dirt can be a protective element, especially for women to reduce risks, such as sexual violence ${ }^{(20)}$.

Divergent representations of drug use among HP may indicate that some professionals are closer to the theme and / or reality of this public. However, the group investigated by highlighting the term "drugs" indicates that their use is recognized as a health problem, or as a way of "anesthetizing" and "escaping from reality", facing the continuous difficulties experienced on the streets that may cause physical and mental exhaustion. In this regard, research conducted in Madrid, Spain, comparing two groups of $\mathrm{HP}$, the first consisting of people under one year living on the streets and the second who lived for more than five years on the street, revealed that the longest stay on the street can increase a person's chances of using alcohol and other drugs more often ${ }^{(21)}$.

There are still few studies that propose that the spaces of academic formation in nursing provide the approximation with the reality of vulnerable groups, especially with HP. Thus, the difficulties of nursing professionals in approaching HP seem to be related to the approach with users and those with the service; the lack of theoretical and conceptual support to guide the work process; and unpreparedness for qualified listening and dealing with alcohol and other drugs ${ }^{(22)}$. The lack of discussions on the subject in the context of higher education and technical nursing may favor the predominance of practices based on empiricism, linked to the previous conceptions of each professional, implying (in) visibility of the health demands of HP.

A study conducted in the state of Bahia, Brazil showed that the proximity of nursing professionals with the context of life of $\mathrm{HP}$ is a factor that favors the recognition of drug use as a way of facing life. This occurs when it is marked by family problems, such as domestic, financial and psychological violence ${ }^{(23)}$, although it is a form of coping that leads to situations of individual and social vulnerability. From this perspective, the professional activity focuses on the person and not the drug, with the intention of reducing damage and social and health problems. In the present research, it was observed that among the professionals who work in specific mental health services or who have a history of acting with HP, the representations connote respect and sensitivity.

Disagreements, situations of physical or sexual abuse, or family abandonment are in the stories of many HP, especially related to drug abuse ${ }^{(24)}$. HP may suffer from family rejection or may choose to move away from their family nucleus. However, 
this is not a standard among street people. The (con) formation of new bonds, whether loving or friendship, can be for many the constitution of new (re) family arrangements, meeting the need for affection that they often did not have in their original family ${ }^{(25)}$. In the context of health services, it is expected that the nursing staff have the competences and skills to deal with these new family arrangements in order to ensure, for example, the monitoring of families within the scope of primary care.

The element "diseases" reveals aspects of the belonging group, recognizing the fragility of HP and the greater susceptibility to acquiring diseases. A multicenter study conducted in six Brazilian state capitals with 546 crack users revealed that those who were homeless at some point in their lives had the worst severity nucleus in alcohol, medical, psychiatric, employment and family support ${ }^{(26)}$. The finding of precariousness in the living conditions of HP mobilizes the nursing staff, generating sadness.

The presence of the elements "care" and "humanity", in the lower left quadrant (Table 1), allows us to infer that the investigated group appreciates the need for differentiated care for HP, due to their vulnerability situation. In this context, care presupposes actions that can deal with their particularities and vulnerabilities, in a challenging and intense way ${ }^{(27)}$. However, the mere provision of services is not a process of care and not every care in practice will be endowed with humanization. These representational elements highlight the importance of providing quality health services that address the specificities of this population.

Professionals working with HP are witnesses to their reports as victims of daily violence. Acts that are practiced in an institutionalized manner, with the endorsement of the state, which include physical violence, retention and destruction of belongings and documents. Violence can come through hygienic acts such as compulsory removal of HP to hostels ${ }^{(10,28)}$. Acts of gentrification can also be considered as violence, as they "revitalize" noble and central areas in large cities, making it difficult or impossible for $\mathrm{HP}$ to stay in certain places ${ }^{(29)}$.

Institutional violence is practiced in public services by state agents, which should guarantee citizens' rights. This type of violence occurs in the way public services are offered, denied or neglected, creating barriers to accessing HP. The services that most commit this type of violence against HP are health, social security and public safety ${ }^{(30)}$. Health services need to be high in plasticity and low in order to ensure that HPs are welcomed and linked, allowing their needs to be identified and effective action taken in the care process ${ }^{(11)}$. The nursing staff is a fundamental part of this process due to the significant quantity of their health service professionals, as well as the relational aspect of their care process.

The marginalization of certain population groups is a consequence of the inadequacy of the modern capitalist mode of production, where the masses have lost the modern references without acquiring the postmodern ones, damaging the social integration of the community ${ }^{(31)}$. Identifying HP as a marginalized group also alludes to society's insecurity and fear. Media campaigns have spread feelings of fear and rejection towards crack users, for example, that can be found in spaces known as cracolândias (derived from crack, crack + lândia = crack land is a popular denomination for an area in downtown São Paulo, where people trade drugs and use them), creating a movement of "counterfeit". It is a term coined by Antonio Lancetti to describe impulsive actions to try to simplistically and quickly solve the complex phenomenon of alcohol use and others ${ }^{(32)}$. In this perspective, HP are seen as people apart from society, compared to the undead, in common sense, being called "zombies", a derogatory term to designate a being devoid of personality or will, who roams the nights.

The ideas of loneliness and mental disorder among HP are related, for the nursing staff, to the breaking of family bonds or their weakening. A study of 16 homeless persons in Sydney, Australia, showed that they suffered stigma, which undermined the way they related to other people, generating loneliness ${ }^{(33)}$. Although networks develop among homeless persons, they can be very small or fragile, marked by forced coexistence and may not be deep enough to promote belonging. Feelings of neglect beyond the context of frequent vulnerability and violence create little ground for strong and stable relationships ${ }^{(33)}$. This fragility of social relations can lead to feelings of loneliness.

Social isolation, associated with other intrinsic and extrinsic factors, can lead to psychic illness of HP. Suffering from a mental disorder is an aggravating factor for health and demands network articulation actions by health services and the intersectoral network ${ }^{(26)}$. A systematic review in Germany revealed that the prevalence of mental disorders among HP can reach $77 \%$. Among the main problems are listed in descending order disorders related to psychoactive substance use, anxiety disorders, mood disorders and psychotic disorders ${ }^{(9)}$.

\section{Study limitations}

This study was carried out in only one of the health districts of Salvador and did not allow to contemplate the specificities of each territory. Even so, the results allowed us to access elements that can contribute to (re) thinking and doing of nursing. The study also did not analyze the representations by sex/gender and by professional category.

\section{Contributions to nursing and public policy}

It is believed that the development of this research points to elements to improve the quality of HP care and, in some way, reduce the difficulties of access of this population to health services. The research process allowed integration between undergraduate and postgraduate students, aroused to citizenship, respect and ethical aspects that involve health care. Latent senses and meanings emerged about the theme investigated, favoring changes in social representations about this group. In addition, the results found provide elements for the creation of possible training strategies and continuing education for professionals of the nursing staff, increasing the intervention capacity of this professional group with HP.

\section{FINAL CONSIDERATIONS}

The data analyzed reveal elements of inequalities that permeate the different societies, establish differences and imply vulnerabilities for people and/or social groups. In this context, 
HP image is anchored in hegemonic representations and stereotypes that can interfere with the provision of care and their access to health services.

Given the evidence of the growth of HP in Brazil and worldwide and the characteristics of the nursing staff's professional practice, it is necessary to implement and/or expand the discussion about the health demands and specificities of HP in training. Within the scope of SUS, the nursing staff represents the largest number of professionals and their practices are focused on care. The social representations of nursing professionals, evidenced in this study, indicate that the insertion of this theme in the various training spaces is relevant. It is important the rapprochement between the students/professionals and $\mathrm{HP}$, with the possibility of dialogues so that the care process is effective and aims at guaranteeing the constitutional rights, among them, the right to health based on the principles of universality, equity, comprehensiveness and humanization.

\section{REFERENCES}

1. Ministério da Saúde (BR). Portaria 3088, de 23 de dezembro de 2011. Institui a Rede de Atenção Psicossocial para pessoas com sofrimento ou transtorno mental e com necessidades decorrentes do uso de crack, álcool e outras drogas, no âmbito do Sistema Único de saúde (SUS) [Internet]. 2011 [cited 2019 Feb 26]. Available from: http://bvsms.saude.gov.br/bvs/saudelegis/gm/2011/prt3088_23_12_2011_rep.html.

2. Machado MH, Oliveira E, Lemos W, Lacerda WF, Aguiar-Filho W, Wermelinger M, et al. Mercado de trabalho da enfermagem: aspectos gerais. Enferm Foco [Internet]. 2016 [cited 2017 Nov 25];7(esp): 35-62. Available from: http://revista.portalcofen.gov.br/index.php/enfermagem/ article/view/691/30

3. Van Wijk LB, Mângia EF. O cuidado a Pessoas em Situação de Rua pela Rede de Atenção Psicossocial da Sé. Saúde Debate. 2017 [cited 2019 Apr 16]; 41(115): 1130-1142. doi: 10.1590/0103-1104201711511.

4. Palácio do Planalto (BR). Decreto 7053 de 23 de dezembro de 2009. Institui a Política Nacional para a População em Situação de Rua e seu Comitê Intersetorial de Acompanhamento e Monitoramento, e dá outras providências. 2009 [cited 2018 Jan 29]. Available from: http:// www.planalto.gov.br/ccivil_03/_ato2007-2010/2009/decreto/d7053.htm.

5. Andrade LP, Costa SL, Marquetti FC. A rua tem um íma, acho que é a liberdade: potência, sofrimento e estratégias de vida entre moradores de rua na cidade de Santos, no litoral do Estado de São Paulo. Saúde Soc. São Paulo. 2014;23(4):1248-61. doi: 10.1590/S0104-12902014000400011

6. Wise C, Philips K. Hearing the silent voices: narratives of health care and homelessness. Iss Mental Health Nurs. 2013; 34: 359-367. doi:10.31 09/01612840.2012.757402

7. Ministério da Saúde (BR). Manual sobre o cuidado à saúde junto à população em situação de rua [Internet]. Brasília, DF. 2012 [cited 2018 Feb 06]. Available from: http://189.28.128.100/dab/docs/publicacoes/geral/manual_cuidado_populalcao_rua.pdf

8. Keogh C, O 'brien KK, Hoban A, O'carroll A, Fahey T. Health and use of health services of people who are homeless and at risk of homelessness who receive free primary health care in Dublin. BMC Health Serv Res. 2015 [cited 2019 Mar 30];15(58):1-8. doi: 10.1186/ s12913-015-0716-4.

9. Schreiter S, Bermpohl F, Krausz M, Leucht S, Rössler W, Schouler-Ocak M, Gutwinski S. The prevalence of mental illness in homeless people in Germany: a systematic review and meta-analysis. Deutsches Arzteblatt International. 2017 [cited 2019 Mar 28];117: 665-72. doi: 10.3238/ arztebl.2017.0665

10. Hallais J, Barros NF. Consultório na Rua: visibilidades, invisibilidades e hipervisibilidade. Cad Saúde Pública. 2015 [cited 2019 Feb 18];31(7):1497-1504. doi: 10.1590/0102-311X00143114

11. Ministério da Saúde (MS). Secretaria de Atenção à Saúde, Departamento de Ações Programáticas Estratégicas. Guia estratégico para o cuidado de pessoas com necessidades relacionadas ao consumo de álcool e outras drogas: Guia AD [Internet]. 2015 [cited 2019 Feb 26]. Available from: http://portalarquivos2.saude.gov.br/images/pdf/2015/dezembro/15/Guia-Estrat--gico-para-o-Cuidado-de-Pessoas-comNecessidades-Relacionadas-ao-Consumo-de---Icool-e-Outras-Drogas--Guia-AD-.pdf.

12. Woith WM, Kerber C, Astroth KS, Jenkins SH. Lessons from the Homeless: civil and uncivil interactions with nurses, self-care behaviors, and barriers to care. Nurs Forum Vol. 2017;52(3): 211-220. doi: 10.1111/nuf.12191

13. Abric JC. Abordagem Estrutural das Representações Sociais: desenvolvimentos recentes. In Campos PHF, Loureiro MCS. Representações Sociais e Práticas Educativas. Goiânia: Editora UCG, 2003.

14. Presidência da República (BR). Diálogos sobre a população em situação de rua no Brasil e na Europa: experiências do Distrito Federal, Paris e Londres. Secretaria de Direitos Humanos da Presidência da República. Brasília: SDH, 2013.

15. Souza MRR, Oliveira JF, Chagas MCG, Carvalho ESS. Gender, violence and being homeless: the experience of women and high-risk drug use. Rev Gaúcha Enferm. 2016;37(3):e59876. doi: 10.1590/1983-1447.2016.03.59876

16. Georges R. A Distância que nos une: um retrato das desigualdades brasileiras. Relatório da Oxfam Brasil [Internet]. 2017 [cited 2019 Mar 31$]$. Available from: https://www.oxfam.org.br/sites/default/files/arquivos/Relatorio_A_distancia_que_nos_une.pdf

17. Resende V. A violação de direitos da população em situação de rua e a violência simbólica: representação discursiva no jornalismo on-line. Rev ALED. 2015 [cited 2019 Mar 31];15(1):71-91. Available from: https://raled.comunidadaled.org/index.php/raled/article/view/24

18. Paul S, Corneau S, Boozary T, Stergiopoulos V. Coping and resilience among ethnoracial individuals experiencing homelessness and mental illness. Int J Soc Psychiatry. 2018;64(2):189-97. doi: 10.1177/0020764017748986 
19. Silva ICN, Santos MVS, Campos LCM, Silva DO, Porcino CA, Oliveira JF. Social representations of health care by homeless people. Rev EsC Enferm USP. 2018;52:e03314. doi: 10.1590/S1980-220X2017023703314

20. Aguiar MM, Iriart JAB. Significados e práticas de saúde e doença entre a população em situação de rua em Salvador, Bahia, Brasil. Cad Saúde Pública. 2012;28(1):115-124. doi: 10.1590/S0102-311X2012000100012

21. Panadero-Herrero S, Muñoz-López M. Salud, calidad de vida y consumo de sustâncias em función del tempo em situación sin hogar. Anal Psicol. 2014;30(1):70-7. doi: 10.6018/analesps.30.1.137911

22. Varela DSS, Silva MDF, Monteiro CFS. Dificuldades de enfermeiros no trabalho com usuários de álcool e outras drogas: revisão integrativa. Rev Enferm UFPE. 2015;9(10):9576-83. doi: 10.5205/reuol.7944-69460-1-SM.091020152

23. Oliveira JF, Paiva MS, Valente CLM. Representações sociais de profissionais de saúde sobre o consumo de drogas: um olhar numa perspectiva de gênero. Ciênc Saúde Coletiva. 2006;11(2):473-81. doi: 10.1590/S1413-81232006000200024

24. Neale J, Stevenson C. Social and recovery capital amongst homeless hostel residents who use drugs and alcohol. Int J Drug Pol. 2015;26:475-483. doi: 10.1016/j.drugpo.2014.09.012

25. Cunha JG, Garcia A, Silva TH, Pinho RC. Novos arranjos: lançando um olhar sobre os relacionamentos interpessoais de pessoas em situação de rua. Gerais, Rev Interinst Psicol[Internet]. 2017 Jun [cited 2019 Mar 31];10(1):95-108. Available from: http://pepsic.bvsalud.org/pdf/gerais/ v10n1/10.pdf

26. Halpern SC, Scherer JN, Roglio V, Faller S, Sordi A, Ornell F, et al. Vulnerabilidades clínicas e sociais em usuários de crack de acordo com a situação de moradia: um estudo multicêntrico de seis capitais brasileiras. Cad Saúde Pública. 2017; 33(6):e00037517. doi: 10.1590/0102-311x00037517

27. Londero MFP, Ceccim RB, Bilibio LFS. Consultation office of/in the street: challenge for a healthcare in verse. Interface. 2014;18(49):251-60. doi: 10.1590/1807-57622013.0738

28. Borysow IC, Furtado JP. Access, equity and social cohesion: evaluation of intersectoral strategies for people experiencing homelessness. Rev Esc Enferm USP. 2014;48(6):1069-76. doi: 10.1590/S0080-623420140000700015

29. Frangella S, Rui T. Corpos Precários: apontamentos para a relação entre corpo e cidade. Política \& Trabalho. Rev Ciênc Soc. 2017;47:23-38. doi: 10.22478/ufpb.1517-5901.2017v1n47.36734

30. Antoni C, Munhós AAR. As violências institucional e estrutural vivenciadas por moradoras de rua. Psicol Estud. 2016;21(4):641-51. doi: 10.4025/psicolestud.v21i4.31840

31. Totaro P. Novos caminhos para a saída da marginalidade social no Brasil. Anál Soc. 2016;219(LI):310-35. Available from: http://www.scielo. mec.pt/pdf/aso/n219/n219a03.pdf

32. Branco NMMC, Silva DV, Soldatelli S. Desconstruindo mitos e preconceitos sobre "loucos" e "drogados": uma proposta de ação educativa para familiares de usuários de álcool e outras drogas na perspectiva da educação popular. Pesqui Prát Psicossoc. 2016;11(3):602-12. Available from: http://seer.ufsj.edu.br/index.php/revista_ppp/article/view/1952

33. Bower M, Conroy E, Perz J. Australian homeless persons' experiences of social connectedness, isolation and loneliness. Health Soc Care Community. 2018;26(2):e241-e248. doi: 10.1111/hsc.12505 